
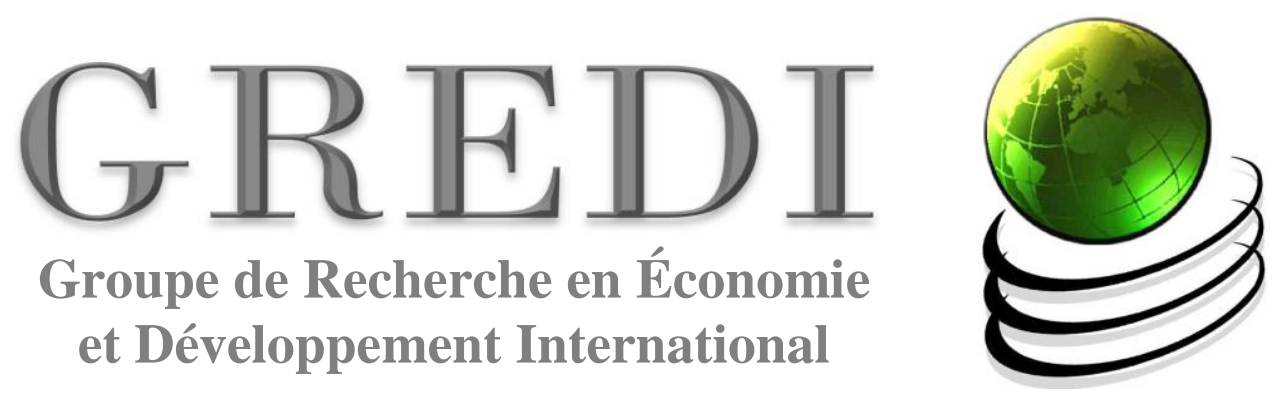

Cahier de recherche / Working Paper

15-13

\title{
International Risk Sharing and Financial Shocks
}

Jean-François ROUILLARD 


\title{
International Risk Sharing and Financial Shocks
}

\author{
Jean-François Rouillard ${ }^{\dagger}$ \\ Université de Sherbrooke \& GREDI
}

November 12, 2015

\begin{abstract}
A canonical two-country real business cycle model with complete international asset markets fails to replicate the sign of the correlation between relative consumptions and real exchange rates-i.e. the consumption-real exchange rate anomaly or Backus-Smith puzzle. When preferences are non-separable between consumption and leisure, the same two-country model augmented by domestic financial frictions and shocks can account for the sign of the Backus-Smith correlation. Specifically, shocks to the firms' borrowing capacity create important fluctuations in the labor wedge, inducing firms to demand more labor following these positive financial shocks. These procyclical movements in hours worked significantly affect the marginal utility of consumption and explain the Backus-Smith correlation. Moreover, the same model under financial autarky predicts a correlation that is far away from its empirical counterpart. This finding suggests that this correlation is not a good indicator of international risk sharing.
\end{abstract}

JEL identification: E44, F34, F44

Keywords: Backus-Smith puzzle, borrowing constraints, labor wedge, working capital, financial shocks, non-separable preferences

\section{Introduction}

Two-country real business cycle models that feature complete international asset markets, international prices, and time-separable preferences satisfy the following condition: the relative marginal utility of consumption is equal to the real exchange rate. For preferences that

\footnotetext{
${ }^{\dagger}$ Assistant Professor - Département d'économique - Université de Sherbrooke \& GREDI - 2500 boul. de l'Université, Sherbrooke, Québec, Canada, J1K 2R1; e-mail: j-f.rouillard@usherbrooke.ca. I thank Huw Lloyd-Ellis, Michel Normandin, Fabrizio Perri, Gregor W. Smith, and two anonymous referees.
} 
also feature separability of consumption from other variables, the relative consumption is proportional to the real exchange rate. However, from data on OECD countries, Backus and Smith (1993) find that these two variables are negatively correlated - I call this correlation the Backus-Smith correlation following Heathcote and Perri (2014). Subsequent work have referred to this anomaly as the Backus-Smith puzzle. The existence of this "puzzle" questions the ability of international financial markets to share risk. In fact, the solution to the social planner's problem would make households consume relatively more when the relative price of consumption is lower (i.e. weaker real exchange rate). In this paper, I explain the "puzzle" from non-separabilities and the effects of shocks to the borrowing capacity of firms. These financial shocks randomly "affect firms' ability to borrow", and are similar to the ones that Jermann and Quadrini (2012) examined. This finding suggests that the Backus-Smith correlation is unrelated to the degree of international efficiency.

The model economy is based on Backus, Kehoe, and Kydland's (1994) (hereafter BKK) two-good, two-country model and augmented by working capital requirements and enforcement constraints that are closely related to the work of Perri and Quadrini (2011). In a similar fashion, countries are populated by two types of agents: investors that own the firms and workers. However, Perri and Quadrini's (2011) main objective is to study the international transmission of financial shocks, not the degree of international risk sharing. Their model also differs on one important aspect - it features a perfectly integrated equity market. This market structure implies that countries are equally affected by financial shocks regardless of their origins. In my model, investors are precluded from holding international assets. The only international financial linkage is through the bond market, as workers are allowed to trade risk-free non-contingent international bonds-i.e. incomplete markets. ${ }^{1}$ As for the goods market, firms of each country specialize in the production of one good, which are considered intermediate goods. The expenditure good is a bundle that consists of both the Home and Foreign intermediate goods. Real exchange rates emerge as the ratio of the prices of the intermediate goods of the two countries.

The financial frictions that firms face are domestically-based only. First, they have working capital requirements for which they borrow to cover the value of their expenses at the beginning of each period (i.e. intra-period loan) and that they need to repay once they receive their revenues. Note that firms also borrow from workers for a longer horizon (i.e.

\footnotetext{
${ }^{1}$ This asset market structure is chosen for computational purposes. However, in the results section, I show that complete markets would also give similar results.
} 
inter-period debt). Second, the firms' total borrowing, intra and inter-period, cannot exceed a random fraction of the value of their collateral assets. In fact, this random fraction is based only on physical collateral assets. This constraint exists in order to prevent costly defaults. In the event of a default in repayment of their loans, borrowers would be able to seize a random fraction of the firms' capital. In equilibrium, it is never optimal for firms to default on their debts.

The mechanism to explain the "puzzle" is split in two parts. First, since firms have borrowing constraints, they do not pay wages that are equivalent to the value of their marginal product (MPN). Theoretically, the difference between these two variables is a component of the labor wedge that is similar to the one identified by Chari, Kehoe, and McGrattan (2007) and Shimer (2009). ${ }^{2}$ Financial shocks play a key role in affecting this wedge. In fact, positive shocks tend to close the gap between wages and the MPN, so firms react by increasing their labor demand. This mechanism is similar to the one exposed by Jermann and Quadrini (2012) in order to generate more volatility in hours worked and GDP.

Second, I assume that workers have GHH preferences (proposed by Greenwood, Hercowitz, and Huffman (1988)), so that consumption and leisure are non-separable in their utility functions. The use of these preferences is not novel in the open-economy literature, see e.g. Correia et al. (1995) and Mendoza (1991). Moreover, Aguiar, Hurst, and Karabarbounis's (2013) empirical findings on the elasticity of home production at business cycle frequencies from time use surveys reinforce the choice of these preferences. In the model, non-separability implies that the marginal utility of consumption is a function of consumption and leisure. Since the relative marginal utility of consumption is equal to the real exchange rate, the sizeable response of hours worked to financial shocks breaks the link between relative consumption and the real exchange rate. Therefore, the negative Backus-Smith correlation is not incompatible with efficient financial markets at the international level.

In the next section, I discuss the related literature. In section 3, I introduce the baseline model that embeds national financial frictions and shocks. In section 4, I present the parameterization that is based on two of the world's largest financial hubs i.e. the United States and the United Kingdom in a period of internationally stronger financial linkages (1984-2010). In section 5, I present the results of the baseline model and some of its variants and conclude in section 6 .

\footnotetext{
${ }^{2}$ See Shimer (2009) for a survey of the literature on the labor wedge and its implications for business cycles.
} 


\section{Related literature}

This paper is related to the work that studies the link between the Backus-Smith puzzle and the efficiency of international financial markets. Heathcote and Perri (2014) show that modifying the complete asset market structure of a canonical two-country, two-good model (i.e. BKK or Heathcote and Perri (2002)) to an incomplete asset market structure or to financial autarky does not solve the "puzzle". Neither do the various specifications of a monetary model that Chari, Kehoe, and McGrattan (2002) examined, e.g. non-separable preferences and habit persistence. Incomplete asset markets even generate a perfect correlation between relative consumptions and real exchange rates. The structure of asset markets, however, is important for Corsetti, Dedola, and Leduc (2008). They can account for the crucial correlation from a similar model that features incomplete asset markets and a very low elasticity of substitution between Home and Foreign intermediate goods. However, their results hinge on the value of this elasticity, in contrast to my results.

Non-separable preferences also play a central role in Raffo's (2010) work. He shows that GHH preferences in conjunction with investment-specific technology (IST) shocks can solve the "puzzle". However, the calibrated volatility of these shocks, as estimated by Mandelman, Rabanal, Rubio-Ramírez, and Vílan (2011), seems to be unrealistically high. Once the cointegration of IST shocks across countries is taken into account, they are no longer able to replicate the negative Backus-Smith correlation. An alternative way to break the link between relative consumptions and the ratio of marginal utilities of consumption is to rely

on preferences that are not time-separable, such as recursive preferences. Ho et al. (2013) use Epstein and Zin (1989) preferences in conjunction with GHH preferences and TFP shocks that are co-integrated. GHH preferences appear to play a central role in explaining the "puzzle".

Benigno and Thoenissen (2008) underline the importance of non-traded goods for real exchange rate dynamics. Their mechanism relies on the Balassa-Samuelsson effect: an increase in productivity of one of the country's tradable sector leads to an increase in the price of their non-tradable goods that translates into an appreciation of the real exchange rate. However, this finding goes against the empirical evidence for the observation that movements in the ratio of non-tradable goods at business cycle frequencies do not contribute significantly to the volatility of real exchange rates, as shown e.g. by Chari, Kehoe, and McGrattan (2002). Karabarbounis's (2014a) framework features a different type of non-traded good, 
i.e. one that originates from home production. Since the consumption basket is composed of market and non-market goods, a labor wedge emerges as the households' marginal rate of substitution between consumption and leisure (MRS) diverges from the wages paid on the labor market. His approach to estimating some parameters of his structural model involves matching moments of the labor wedge and other closed-economy variables. His model explains many open-economy puzzles including the Backus-Smith puzzle and emphasizes the importance of non-separable preferences and the labor wedge. In my model, the variation in the labor wedge is driven by financial shocks, rather than non-market productivity shocks.

Following the closed-economy literature on optimal dynamic contracts, Kehoe and Perri (2002) and Bai and Zhang (2012) also have an endogenously-determined incomplete asset market structure that they introduce through a limited enforcement problem so that countries can default on their loans. They show that these distortions in international credit markets are important to explain the degree of international risk sharing. However, financial frictions in my model take place within countries rather than at the international level. Domestic financial frictions are central to the mechanisms proposed by other work, but they do not address issues related to international risk sharing or, specifically, the Backus-Smith puzzle. Neumeyer and Perri (2005) make use of these financial frictions in an open-economy setting to replicate stylized facts of emerging economies business cycles. Iacoviello and Minetti (2006) examine the role of location-sensitive liquidation costs in explaining the high-level of co-movements across industrialized countries. Rouillard (2015) shares the same objective; however, the mechanism involves variations in the wedge between the real interest rate and the marginal product of capital, which is a result of financial frictions. Finally, Devereux

and Yetman (2010) investigate the international transmission of productivity shocks in an environment where debt and equity markets are integrated internationally.

\section{The business-cycle model}

The baseline model is an extension of the two-good, two-country model developed by BKK. In fact, domestic financial markets are examined in more details as they encompass frictions and shocks. In this respect, the model shares similarities with Perri and Quadrini (2011). As mentioned in the last section, these frictions are limited to domestic financial markets. I depart from BKK by assuming that there are two categories of households in each country: investors and workers. Their fractions in total population are respectively $1-\varpi$, and $\varpi$. 
Investors own the domestic firms and consume their dividends, while workers work, consume their labor income, and trade financial assets (i.e loans to domestic firms and international bond traded with households from abroad). Firms in each country specialize in the production of one good, so that the expenditure is the aggregation of the domestically-produced good and the imported good. They face working capital requirements and have borrowing constraints in a similar fashion to Hart and Moore (1994) and Jermann and Quadrini (2012). Note that the complete derivation of the recursive problems of the firms, investors, and workers appears in Appendix B.

\subsection{Production}

There are two stages to production. Firms use labor $n_{i t}$ and capital $k_{i t}$ to produce intermediate goods. I assume a Cobb-Douglas production function:

$$
y_{i t}=A_{i t} k_{i t-1}^{\mu} n_{i t}^{1-\mu}
$$

where the subscript $i$ takes two values: $H$ for Home and $F$ for Foreign. The parameter $\mu$ corresponds to the fraction of capital in output, and $A_{i t}$ to the country-specific TFP shock.

Firms in each country produce differentiated goods. The Home country specializes in good $a$ and the Foreign country in good $b$. The expenditure good that is used for consumption

and investment motives is a bundle consisting of goods $a$ and $b$, as shown from the following equation:

$$
\begin{aligned}
G\left(a_{H t}, b_{H t}\right) & =\left[\omega^{\epsilon+1} a_{H t}^{-\epsilon}+(1-\omega)^{\epsilon+1} b_{H t}^{-\epsilon}\right]^{-\frac{1}{\epsilon}}, \\
G\left(a_{F t}, b_{F t}\right) & =\left[(1-\omega)^{\epsilon+1} a_{F t}^{-\epsilon}+\omega^{\epsilon+1} b_{F t}^{-\epsilon}\right]^{-\frac{1}{\epsilon}}
\end{aligned}
$$

where the subscripts correspond to the country in which the final stage of production takes place, $\omega>0.5$ governs the degree of home bias, and the elasticity of substitution between Home and Foreign intermediate goods is given by $\sigma=1 /(1+\epsilon)$.

Since firms are operating in a perfectly competitive market, the equilibrium prices of goods $a$ and $b$ are given by their marginal products:

$$
p_{H i t}=\partial G\left(a_{i t}, b_{i t}\right) / \partial a_{i t}, \quad p_{F i t}=\partial G\left(a_{i t}, b_{i t}\right) / \partial b_{i t} .
$$


where the first subscript of the prices corresponds to the location of the production of the intermediate good and the second subscript to the location of the final good's production. For example, $p_{H H t}$ corresponds to the price of good $a$ in the Home country with $i=\{H, F\}$.

The price level of the final good is an aggregate of these two goods:

$$
P_{H t}=\left(\omega p_{H H t}^{\frac{\epsilon}{1+\epsilon}}+(1-\omega) p_{F H t}^{\frac{\epsilon}{1+\epsilon}}\right)^{\frac{1+\epsilon}{\epsilon}} .
$$

\subsection{Real exchange rate and terms of trade}

For the Home economy, real exchange rates are defined as the ratio of these prices in the Foreign and Home countries:

$$
Z_{H t}=\frac{P_{F t}}{P_{H t}}=\frac{\left(\omega p_{F H t}^{\frac{\epsilon}{1+\epsilon}}+(1-\omega) p_{H H t}^{\frac{\epsilon}{1+\epsilon}}\right)^{\frac{1+\epsilon}{\epsilon}}}{\left(\omega p_{H H t}^{\frac{\epsilon}{1+\epsilon}}+(1-\omega) p_{F H t}^{\frac{\epsilon}{1+\epsilon}}\right)^{\frac{1+\epsilon}{\epsilon}}}
$$

The definition of terms of trade in this framework is the price of good $b$ in terms of the price of $\operatorname{good} a$ :

$$
\begin{aligned}
\operatorname{TOT}_{H t} & =\frac{p_{F H t}}{p_{H H t}}=\frac{1-\omega}{\omega}\left(\frac{a_{H t}}{b_{H t}}\right)^{1+\epsilon} \\
& =\frac{p_{F F t}}{p_{H F t}}=\frac{\omega}{1-\omega}\left(\frac{a_{F t}}{b_{F t}}\right)^{1+\epsilon} .
\end{aligned}
$$

Note that for the Foreign economy, real exchange rates and terms of trade are simply the inverse of the values for the Home economy.

\section{$3.3 \quad$ Firms}

Since the final good is the numéraire, the relative price of intermediate goods is $p_{i i t}$ and the intermediate firms' revenues from sales correspond to $p_{i i t} y_{i t}$. Firms' spending is the sum of the wage bill $w_{i t} n_{i t}$, investment $x_{i t}$, and dividends $d_{i t}$ paid to shareholders. Their net borrowing corresponds to $e_{i t}^{P}-R_{i t-1} e_{i t-1}^{P}$, where $e_{i t}^{P}$ corresponds to the level of inter- 
period debt and $R_{i t}$ to the interest rate. The following budget constraint combines revenues, spending, and borrowing as follows:

$$
p_{i i t} y_{i t}+e_{i t}^{P}=d_{i t}+x_{i t}+R_{i t-1} e_{i t-1}^{P}+w_{i t} n_{i t}
$$

Capital's law of motion is simply given by $k_{i t}=(1-\delta) k_{i t-1}+x_{i t}$, where $\delta$ corresponds to the depreciation rate. I assume that firms collect revenues only after having paid their factors of production and dividends only after having borrowed. Hence, in order to cover these expenses, they contract intra-period loans $l_{i t}$ :

$$
l_{i t}=R_{i t-1} e_{i t-1}^{P}-e_{i t}^{P}+d_{i t}+x_{i t}+w_{i t} n_{i t} .
$$

It is an identity that these loans correspond exactly to output. Firms may decide to renege on their total debt i.e. the sum of intra-period loans and inter-period debt. However, in this case I assume that lenders would be able to repossess a stochastic fraction $-\lambda_{i t}$, i.e. the financial shock - of the value of the firms' capital holdings. Therefore, in equilibrium, firms never default and workers impose the following borrowing constraint:

$$
\lambda_{i t} k_{i t} \geq l_{i t}+e_{i t}^{P}
$$

This borrowing constraint is the equilibrium result of an enforceability problem for which it is assumed that firms have all the bargaining power. The complete derivation of the problem is described in Appendix A of Perri and Quadrini (2011). The firms' objective is to maximise the discounted stream of dividends. Since they face a borrowing constraint, they do not pay factors of production the values of their marginal products. The firms' first order condition with respect to labor is as follows:

$$
p_{i i t} y_{n_{i t}}=\frac{w_{i t}}{1-\vartheta_{i t}}
$$

where $y_{n_{i t}}$ corresponds to the marginal product of labor and $\vartheta_{i t}$ to the Lagrange multiplier on the borrowing constraint. A relaxed borrowing constraint, caused by a positive financial shock for example, leads to lower levels of the Lagrange multiplier $\vartheta_{i t}$. Firms adjust their labor demand according to this condition and this appears crucial in explaining the BackusSmith puzzle. This is further explored in section 5. 


\subsection{Investors}

Investors hold shares of domestic firms only. This assumption will be relaxed in the sensitivity analysis section to allow them to hold shares of foreign firms as well. They derive utility from consuming the final goods intertemporally as follows: $E_{0} \sum_{t=0}^{\infty} \gamma^{t} \ln c_{i t}^{P}$, where $\gamma$ corresponds to their discount factor. They face the following budget constraint:

$$
s_{i t}\left(d_{i t}+p_{i t}^{s}\right)=c_{i t}^{P}+p_{i t}^{s} s_{i t+1}
$$

where $s_{i t}$ corresponds to shares and $p_{i t}^{s}$ to their market price. In equilibrium, their stochastic discount factor corresponds to that of the firms'.

\subsection{Workers}

Workers maximize the discounted sum of period-specific utilities, as follows:

$$
E_{0} \sum_{t=0}^{\infty} \beta_{i t}^{t} U\left(c_{i t}^{W}, n_{i t}\right)
$$

where $\beta_{i t}$ corresponds to their discount factor and $c_{i t}^{W}$ to their consumption of final goods. Their period-specific utility functions are non-separable and are based on the work of Greenwood, Hercowitz, and Huffman (1988):

$$
U\left(c_{i t}^{W}, n_{i t}\right)=\ln \left(c_{i t}^{W}-\frac{\zeta}{\eta} n_{i t}^{\eta}\right),
$$

where $\zeta>0, \eta>1$, and $c_{i t}^{W}$ is their consumption of final goods. I also adopt an endogenous discount factor to ensure stationarity of the model in a similar fashion to Mendoza (1991):

$$
\beta_{i t}=\left(1+\exp \left(U\left(c_{i t}^{W}, n_{i t}\right)\right)\right)^{-\varsigma_{W}}
$$

However, this adjustment is strictly to stationarize the model and does not affect dynamics.

As mentioned in the firms' section, workers lend to firms. Loans are of two types intra-period $l_{i t}$ and inter-period $e_{i t}^{W}$. They also trade an international bond with workers from abroad $f_{i t}$ that is denominated in terms of the Foreign's final good. Workers are paid 
for the hours worked and consume $c_{i t}^{W}$. The budget constraint for the Home-country workers is the following: ${ }^{3}$

$$
R_{H t-1} e_{H t-1}^{W}+Z_{H t} R_{t-1} f_{H t-1}+w_{H t} n_{H t}=c_{H t}^{W}+e_{H t}^{W}+Z_{H t} f_{H t} .
$$

The key first order condition to explain the lack of international risk sharing is the one with respect to the international bond. ${ }^{4}$ In conjunction with the FOCs with respect to consumption, the following equation emerges:

$$
E_{t} \hat{u}_{c_{F t+1}^{W}}-E_{t} \hat{u}_{c_{H t+1}^{W}} \approx E_{t} \hat{z}_{t+1}
$$

where $\hat{x}_{t}$ is equal to the growth rate of $X_{t}$, i.e. $\hat{u}_{c_{F t+1}^{W}}=\log \left(U_{c_{F t+1}^{W}} / U_{c_{F t}^{W}}\right), \hat{u}_{c_{H t+1}^{W}}=$ $\log \left(U_{c_{H t+1}^{W}} / U_{c_{H t}^{W}}\right)$, and $\hat{z}_{t+1}=\log \left(Z_{t+1} / Z_{t}\right)$. Therefore, expected changes in marginal utilities of consumption are proportional to expected changes in real exchange rates under incomplete asset markets, since variations in discount factors $\beta_{H t}$ and $\beta_{F t}$ are negligible. ${ }^{5}$ From the GHH preferences specified in the workers' problem, the marginal utility of consumption corresponds to $\left(c_{i t}^{W}-\frac{\zeta}{\eta} n_{i t}^{\eta}\right)^{-1}$. Hence, large fluctuations in hours worked can break the link between real exchange rates and relative consumptions.

GHH preferences also dampen the wealth effect; consequently, changes in the labor supply are proportional to changes in wages as can be seen from the first order condition with respect to hours worked:

$$
\zeta n_{i t}^{\eta-1}=w_{i t} .
$$

\footnotetext{
${ }^{3}$ The only difference for Foreign workers' budget constraint is that the real exchange rate does not show up.

${ }^{4} \mathrm{As}$ an alternative to the international bond, I could allow households to lend to firms that are located in a different country as well, in similar fashion to Devereux and Yetman (2010). Since international asset markets are frictionless, this alternative specification would give the same results.

${ }^{5}$ Under complete markets, the ratio of marginal utility consumption is equal to the real exchange rate, i.e. $\frac{U_{c W} W}{U_{c_{H t}} W}=Z_{t}$.
} 


\subsection{Labor wedge}

The labor wedge is defined as the difference between the MPN and the MRS. From the workers' optimization problem, it can be shown that the MRS is always equal to wages. Hence, movements in the labor wedge originate entirely from the financial shocks that create a varying gap between the MPN and wages. In a similar fashion to Karabarbounis (2014a), I present theoretical, $\tau_{i t}$, and empirical, $\tau_{i t}^{e}$, expressions of the labor wedge. From equation (11), the theoretical labor wedge is as follows:

$$
\tau_{i t}=\frac{p_{i i t} y_{n i t}}{w_{i t}}=\left(1-\vartheta_{i t}\right)^{-1}
$$

Note that the two-good structure involves different valuations of the MPN and the MRS. This needs to be taken into account when measuring the labor wedge. The empirical counterpart is the following:

$$
\tau_{i t}^{e}=\frac{p_{i i t}(1-\mu) y_{i t} / n_{i t}}{P_{i t} \zeta n_{i t}^{\eta-1}}
$$

where $\frac{P_{i t}}{p_{i i t}}=\left(\omega+(1-\omega) T O T_{i t}^{\frac{\epsilon}{1+\epsilon}}\right)^{\frac{1+\epsilon}{\epsilon}}$. The use of GHH preferences implies that consumption is excluded from the MRS as wealth effects are dampened. Moreover, terms of trade deviations do not contribute much to the variations in the labor wedge.

\subsection{Shocks}

The baseline model features four shocks: two TFP shocks and two financial shocks that follow a multivariate autoregressive process:

$$
\Omega_{t}=\Gamma \Omega_{t-1}+\varepsilon_{t}, \varepsilon_{t} \sim N(0, \Sigma)
$$

where $\Omega_{t}=\left[A_{H t}, A_{F t}, \lambda_{H t}, \lambda_{F t}\right]^{\prime}$ and $\varepsilon_{t}=\left[\varepsilon_{A_{H t}}, \varepsilon_{A_{F t}}, \varepsilon_{\lambda_{H t}}, \varepsilon_{\lambda_{F t}}\right]^{\prime}$. The parameter $\Sigma$ corresponds to the variance-covariance matrix. 


\subsection{Market clearing}

Intermediate goods produced are ensured to be used as inputs in the production of final goods:

$$
\begin{aligned}
& y_{H t}=a_{H t}+a_{F t}, \\
& y_{F t}=b_{H t}+b_{F t} .
\end{aligned}
$$

For the final goods' market, total production of intermediate goods is equal to domestic absorption:

$$
c_{i t}^{P}+c_{i t}^{W}+x_{i t}=G\left(a_{i t}, b_{i t}\right) \text { where } i=\{H, F\} .
$$

The inter-period debt's clearing condition is:

$$
(1-\varpi) e_{i t}^{P}+\varpi e_{i t}^{W}=0
$$

The international bonds market clears:

$$
Z_{t} f_{H t}+f_{F t}=0
$$

\subsection{Recursive competitive equilibrium}

Definition 1. In each country (where $i=\{H, F\}$ and $j=\{H, F\}$, but $i \neq j$ ), a recursive competitive equilibrium is defined as a set of functions for

(i) workers' policies $c_{i}^{W}(\boldsymbol{s}), n_{i}(\boldsymbol{s}), f_{i}(\boldsymbol{s}), e_{i}^{W}(\boldsymbol{s})$;

(ii) investors' policies $c_{i}^{P}(\boldsymbol{s})$

(iii) firms' policies $d\left(s ; k, e_{i}^{P}\right), n\left(s ; k, e_{i}^{P}\right), k\left(s ; k, e_{i}^{P}\right)$ and $e_{i}^{P}\left(s ; k, e_{i}^{P}\right)$;

(iv) firms' value $V\left(s ; k, e_{i}^{P}\right)$;

(v) aggregate prices for each country $w(s), R(s), R_{i}(s), p_{i i}(s), p_{i j}(s), P_{i}(s)$ and $m\left(s, s^{\prime}\right)$;

(vi) law of motion for the aggregate state $s^{\prime}=\Psi(s)$.

Such that:

(i) workers' policies satisfy conditions (34-36); 
(ii) investors' policies satisfy conditions (33);

(iii) firms' policies are optimal and $V\left(\boldsymbol{s} ; k, e_{i}^{P}\right)$ satisfies the Bellman's equation (28);

(iv) wages, interest rates, and prices clear the labor, bond markets, intermediate goods markets (19) and (20), and the stochastic discount factor is $m\left(\boldsymbol{s}, \boldsymbol{s}^{\prime}\right)=\gamma U_{c^{P^{\prime}}} / U_{c^{P}}$;

(v) the resource constraint (21) is satisfied;

(vi) the law of motion in each country $\Psi(s)$ is consistent with individual decisions and the stochastic processes for $A_{i}$ and $\lambda_{i}$.

\section{Calibration}

In this section, I report parameters that govern the shock processes and other parameters that are related to preferences, technology, and credit. The persistence and variance-covariance matrices are estimated from data on the UK and the US. Data sources and the construction of some of these variables are available in Appendix A. It would be interesting to construct the shocks from an aggregate of European countries; however, harmonized series on credit variables are essential in constructing financial shocks, and these series are not available for a long enough period of time.

\subsection{Technology and financial shocks}

First, I present the method that I use to extract these shocks. Second, I show the results of the estimation procedure.

In a similar fashion to Jermann and Quadrini (2012), I log-linearize the intermediategood production functions and consider technology shocks as Solow residuals:

$$
\widehat{A_{i t}}=\widehat{Y_{i t}}-\mu \widehat{k_{i t-1}}-(1-\mu) \widehat{n_{i t}}
$$

where $\widehat{Y_{i t}}, \widehat{k_{i t}}$ and $\widehat{n_{i t}}$ are deviations in logarithms from a linear trend. For example, $\widehat{Y_{i t}}=$ $\log \left(Y_{i t}\right)-\widehat{\beta_{0}}-\widehat{\beta_{1}} t$ where $\widehat{\beta_{0}}$ and $\widehat{\beta}_{1}$ are estimated from an OLS regression.

In order to retrieve financial shocks, I assume that the firms' borrowing constraint, equation (10), always binds. In the simulation of the baseline model, this constraint does not always bind for large positive shocks. However, for a reasonable calibration of the shocks' variance, these events occur with low probability. In fact, quantitative results and dynamics 
Table 1: Parameterization of shock processes

\begin{tabular}{|c|c|c|c|c|c|c|c|}
\hline $\begin{array}{l}\text { Financial } \\
\text { shocks only }\end{array}$ & $\widehat{\Gamma}=$ & $\begin{array}{ll}0 & 0 \\
0 & 0 \\
0 & 0 \\
0 & 0\end{array}$ & $\begin{array}{c}0 \\
0 \\
0.979 \\
-0.01\end{array}$ & $\begin{array}{c}0 \\
0 \\
-0.01 \\
0.979\end{array}$ & & $\begin{array}{l}\hat{\sigma}_{\lambda_{U S}} \\
\hat{\sigma}_{\lambda_{U K}} \\
\hat{\rho}_{\lambda_{U S}, \lambda_{U K}}\end{array}$ & $\begin{array}{ll}= & 0.0109 \\
= & 0.0109 \\
= & 0.27\end{array}$ \\
\hline $\begin{array}{l}\text { Both } \\
\text { shocks }\end{array}$ & $\widehat{\Gamma}=$ & $\begin{array}{c}0.993 \\
0.01 \\
0.035 \\
0.025\end{array}$ & $\begin{array}{l}0.01 \\
0.993 \\
0.025 \\
0.035\end{array}$ & $\begin{array}{c}-0.027 \\
-0.072 \\
0.974 \\
0.002\end{array}$ & $\begin{array}{l}-0.072 \\
-0.027 \\
0.002 \\
0.974\end{array}$ & $\begin{array}{l}\hat{\sigma}_{A_{U S}}= \\
\hat{\sigma}_{A_{U K}}= \\
\hat{\sigma}_{\lambda_{U S}}= \\
\hat{\sigma}_{\lambda_{U K}}=\end{array}$ & $\begin{array}{l}0.0061 \\
0.0061 \\
0.0102 \\
0.0102\end{array}$ \\
\hline & $\widehat{\rho}=$ & $\begin{array}{l}1.00 \\
0.15 \\
0.243 \\
-0.02\end{array}$ & $\begin{array}{c}1.00 \\
-0.02 \\
0.243\end{array}$ & $\begin{array}{l}1.00 \\
0.15\end{array}$ & & & \\
\hline
\end{tabular}

are not affected significantly when I take into account non-linearities associated with nonbinding constraints. ${ }^{6}$ The approximated value of these shocks is:

$$
\widehat{\lambda_{i t}} \approx-\widehat{k_{i t}}+\frac{1}{e^{P}+\bar{Y}}\left(\overline{e^{P}} \widehat{e_{i t}^{P}}+\bar{Y} \widehat{Y_{i t}}\right)
$$

$e^{\bar{P}}$ and $\bar{Y}$ correspond to steady-state levels.

After retrieving the shocks $\left(\widehat{A_{H t}}, \widehat{A_{F t}}, \widehat{\lambda_{H t}}, \widehat{\lambda_{F t}}\right)$, I substitute their values in equation (18) and estimate the persistence and variance parameters by maximum likelihood. I impose symmetry to the matrices, so that persistence, spill-over, and variance parameters are the same for both countries. I present the results in Table 1 for the estimation of financial shocks only and for both types of shocks. The parameters $\hat{\sigma}$ and $\hat{\rho}$ correspond to the estimated standard errors of the shocks and to the estimated correlations of innovations.

\subsection{Preferences and technology parameters}

The remaining parameters are set so that they match some steady-state targets and one moment outside the steady-state for the US. Following the two-country real business cycle literature, I assume symmetry - i.e. both countries are the same size and their parameters

\footnotetext{
${ }^{6}$ For that matter, I have used OccBin - a toolkit developed by Guerrieri and Iacoviello (2015) that proposes a piecewise linear solution to occasionally binding constraints.
} 
Table 2: Parameterization of preferences, technology, and credit

\begin{tabular}{lcl}
\hline Symbol & Value & Definition \\
\hline$\varpi$ & & \\
Preferences & & \\
$\varsigma_{W}$ & 0.5 & share of investors in the economy \\
$\gamma$ & 0.048 & workers discount factor \\
$\eta$ & 0.97 & investors discount factor \\
$\zeta$ & 1.67 & parameter controlling the labor wage elasticity \\
Technology & 4.2 & labor disutility weight \\
$\mu$ & & \\
$\delta$ & 0.36 & capital share \\
$\omega$ & 0.025 & capital depreciation \\
$\sigma=1 /(1+\epsilon)$ & 0.85 & weight on domestic good \\
Credit & 0.85 & elasticity of substitution between intermediate goods \\
$\bar{\lambda}$ & & \\
\hline
\end{tabular}

are also the same. I report them in Table 2. Following Campbell and Mankiw (1990), who find that half of the households are borrowing-constrained, I set the number of investors and workers in both countries to be equal $(\varpi=0.5)$. I set $\varsigma_{W}$ to 0.048 , so that the workers' discount factor is 0.99 - a value that corresponds to an annual real interest rate of 4 percent. The investors' discount factor is lower, $\gamma=0.97$, in order for them to have some incentives to borrow. In that regard, I follow Bernanke, Gertler, and Gilchrist's (1999) calibration, since the interest rate premium is two percentage points. The parameter $\eta$ is set to 1.67 , which corresponds to a labor Frisch elasticity of 1.5. Also, in the utility function, the parameter $\zeta$ is set to 4.2 in order for workers to allocate $30 \%$ of their time to work.

Capital depreciates at a $\delta=0.025$ quarterly rate and the share of capital, $\mu$, in the production function is 0.36 . For the final goods production, I assume that in the steady state the fraction of imported intermediate goods corresponds to $15 \%$, therefore $\omega=0.85$. From 1984 to 2010, this number is also the average fraction for the United States. The elasticity of substitution between intermediate goods produced in the Home and in the Foreign countries is set to $\sigma=0.85$, in a similar fashion to Bodenstein (2011) and Heathcote and Perri (2002). I test the robustness of my results with respect to the value of this parameter in 
the sensitivity analysis section. The enforcement parameter, $\bar{\lambda}$, is estimated by matching the relative standard deviation of hours worked on output. I chose this moment because financial shocks significantly affect the labor wedge and labor demand. In fact, the larger value $\bar{\lambda}$ takes, the larger are the estimated variance of financial shocks and the volatility of hours worked over real GDP. The estimate of $\bar{\lambda}, 0.288$, corresponds to a low leverage scenario for capital, but is close to the estimate, 0.1965 , of a similar parameter by Jermann and Quadrini (2012).

\subsection{Time series of technology and financial shocks}
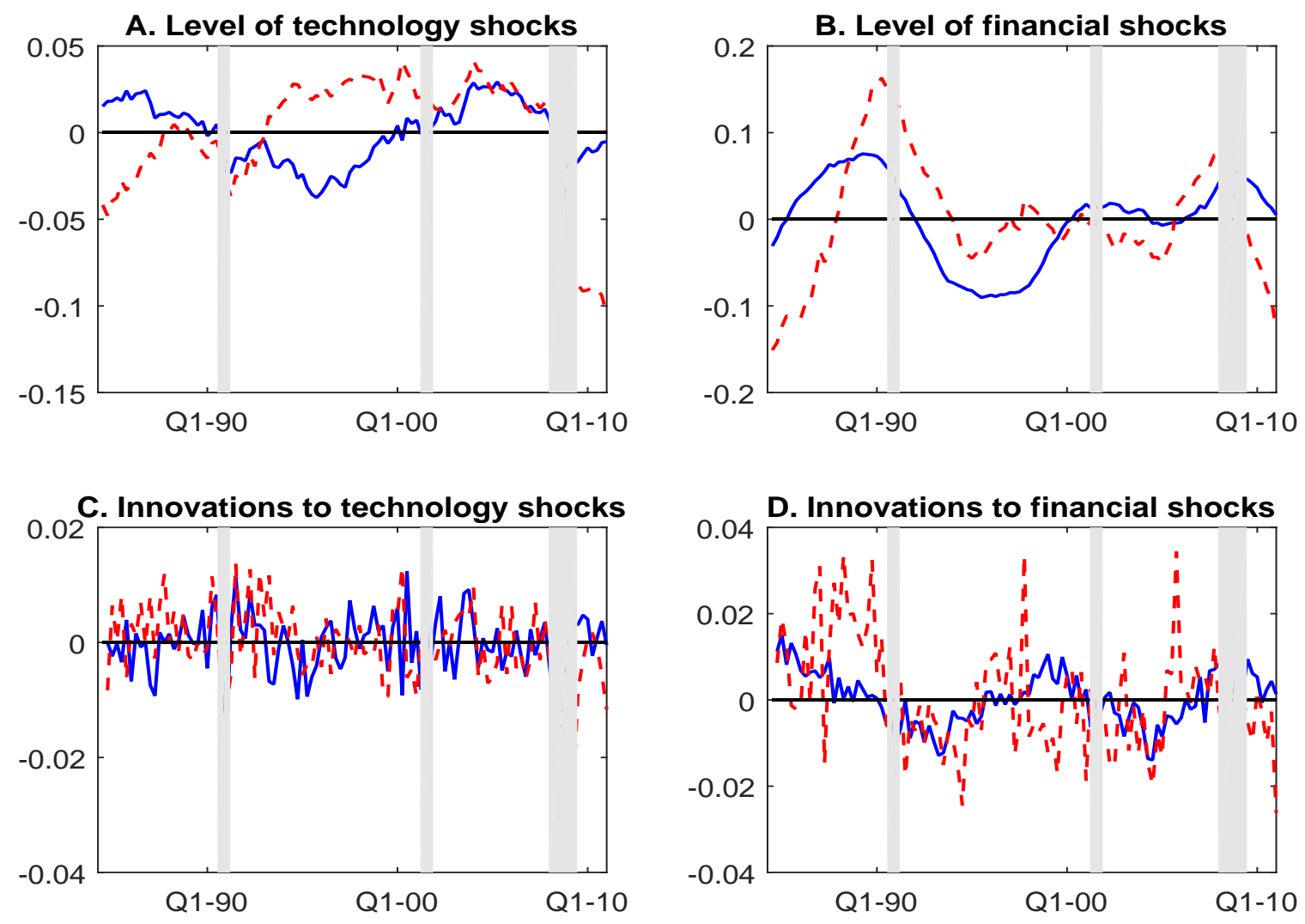

Figure 1: Time series of technology and financial shocks

The solid blue lines correspond to the US, and the dashed red line to the UK. The grey shaded areas represent the corresponding NBER recession for the US.

Prior to turning to the analysis of impulse responses and business cycle statistics, Figure 
1 presents the behavior of the estimated technology and financial shocks throughout time. As can be seen in panel B of Figure 1, it appears that the UK financial shock is more volatile than its US counterpart. In effect, the variable that measures banking loans to non-financial firms displays a standard deviation that is 1.66 times greater for the UK. Moreover, falls in the financial shocks are tied with the onset of recessions. The drop in financial shocks takes place a few quarters before the 1990-1991 recession. However, during the 2001 recession, financial shocks remain at the same level. Finally, the decline in financial shocks lags the beginning of the Great Recession.

\section{Results of the business cycle estimation}

I linearize the system of equations that combines firms, investors and workers' FOCs, and the constraints they face, and I examine the dynamics around the steady state. First, I analyze the impulse responses to financial shocks. Second, I compare business cycle statistics generated by the baseline model to the data.

\subsection{Impulse responses}

In Figure 2, I present impulse responses of key aggregate variables to a one-percent temporary financial shocks that hit the Home economy. The effects of financial shocks are short-lived, despite the high value (0.974) of its persistence parameter. This result is similar to Jermann and Quadrini (2012). The two bottom panels are the most important in studying the BackusSmith correlation. As shown in equation (11), a labor wedge between wages and the marginal product of labor arises due to working capital requirements. A positive shock relaxes the amount of intra-period loans that firms are required to contract. As a consequence, firms raise their demand for labor. In equilibrium, wages are higher following a positive shock in order to induce workers to allocate more time at work, while the marginal product of labor is lower because labor increases more proportionally with capital. ${ }^{7}$

\footnotetext{
${ }^{7}$ Galí, Gertler, and López-Salido (2007) and Karabarbounis (2014b) invalidate firms-based variations in the labor wedge as they present empirical evidence that points to much greater deviations of the MRS from wages. However, the way that wages are measured cannot be directly compared to their theoretical counterparts. On that note, Arellano, Bai, and Kehoe (2012), whose framework embeds financial frictions that induce firms-side variations in the labor wedge, reply that the long-term relationship between employees and employers is not taken into account in theoretical models.
} 

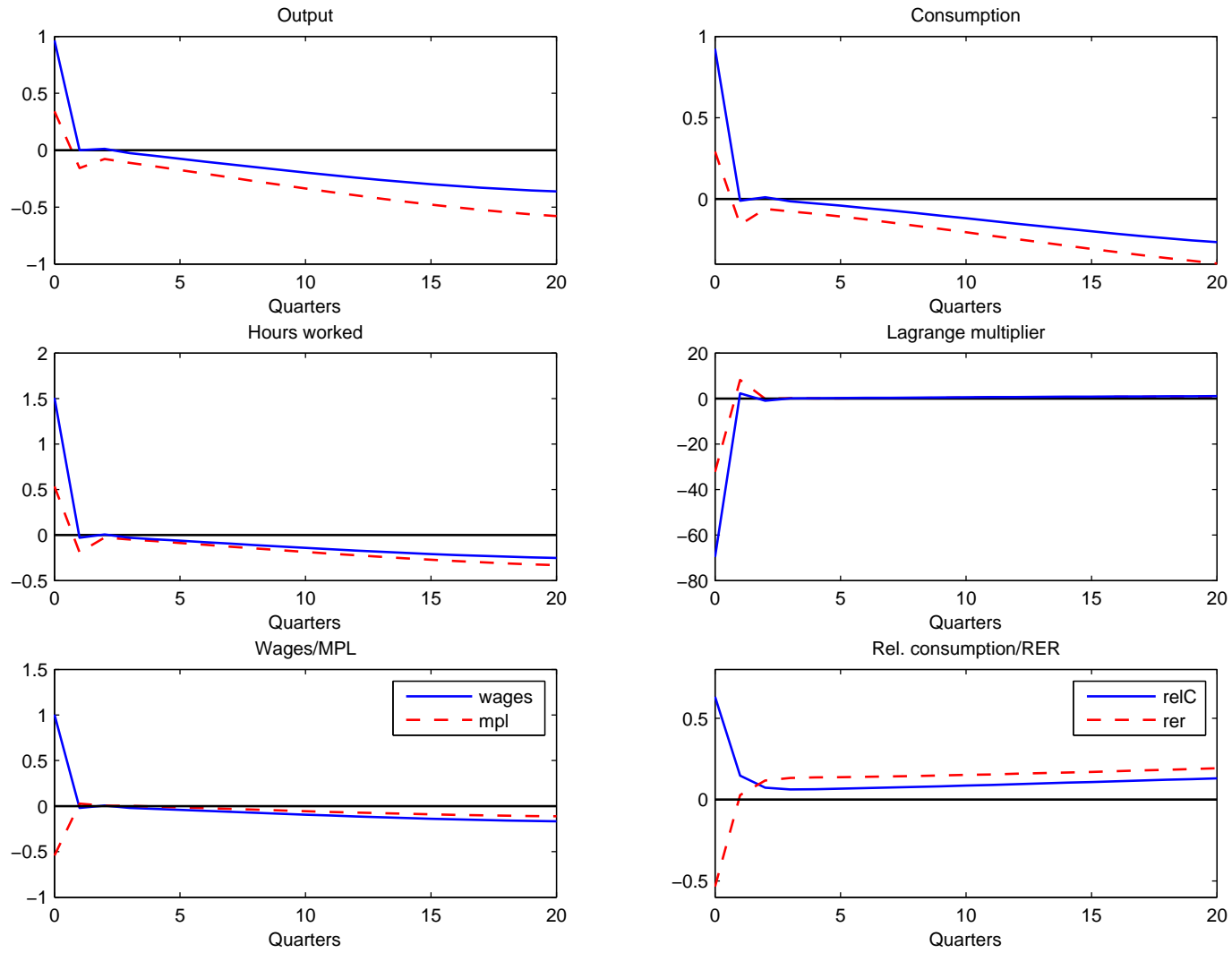

Figure 2: Impulse responses to a one percent temporary Home financial shock

The solid blue lines correspond to the Home economy and the dashed red lines to the Foreign economy. Responses are all measured in percentage deviations from their steady state.

Since preferences are non-separable between consumption and leisure, sizeable variations in hours worked break the link between relative consumptions and real exchange rates. In order to shed light on the role played by financial frictions, I substitute $\zeta n_{H t}^{\eta}$ and $\zeta n_{F t}^{\eta}$ from the firms' labor demand conditions (11) and workers' labor supply (15) in equation (14), so that:

$$
\frac{E_{t}\left(\Delta\left(c_{H t+1}^{W}-\frac{(1-\mu)}{\eta} Y_{H t+1}\left(1-\vartheta_{H t+1}\right)\right)\right)}{E_{t}\left(\Delta\left(c_{F t+1}^{W}-\frac{(1-\mu)}{\eta} Y_{F t+1}\left(1-\vartheta_{F t+1}\right)\right)\right)}=\frac{\beta_{H t}}{\beta_{F t}} E_{t} \Delta Z_{t+1} .
$$

As can be seen in Figure 2, the Lagrange multipliers' responses are large; hence, their contribution to real exchange dynamics are also large. I do not present the impulse responses to technology shocks, but it is important to know that they do not account for much in the 
movements of the labor wedge. ${ }^{8}$

The incomplete market structure implies that the expected growth in the inverse of the marginal utility of consumption ratio is equal to the expected growth in the real exchange rate. For the baseline model, expectations play a minimal role in replicating the crucial negative correlation. In fact, in a complete markets structure, expectations would be removed from equation (11), so that:

$$
\frac{c_{H t}^{W}-\frac{\zeta}{\eta} n_{H t}^{\eta}}{c_{F t}^{W}-\frac{\zeta}{\eta} n_{F t}^{\eta}}=Z_{t} .
$$

This equation almost holds when incomplete markets are assumed in the baseline model, as the correlation between the left-hand and right-hand sides is 0.93 . This suggests that financial frictions and non-separabilities are key elements in breaking the link between relative consumptions and real exchange rates. Implications of this result on international efficiency are discussed in the next section.

\subsection{Quantitative analysis}

\subsubsection{Baseline model}

In Table 3, I present various moments (volatility, autocorrelation, and international correlations) that are generated by the baseline model. I then compare them to the data. With the exception of real exchange rates, all standard deviations, autocorrelations and domestic correlations are averages of the UK and US data. I examine the role of financial shocks as the only source of shocks to account for these moments; additionally, I also observe financial shocks in conjunction with technology shocks. I also report the fraction of periods where the borrowing constraints are not binding and, from a variance decomposition, I report the percentage of GDP that is explained by financial shocks.

A first observation is that the hours worked and labor wedges are more volatile in the

\footnotetext{
${ }^{8}$ It has to be noted that relative consumptions, as measured from the model, consist in the ratio of the sum of investors and workers' consumptions. However, the fluctuations in this variable are mostly driven by workers' consumption or the category of agents that are linked internationally. Therefore, the analysis concerning the relationship between relative consumptions and the workers' ratio of marginal utilities stands true.
} 
Table 3: Business cycle statistics

\begin{tabular}{|c|c|c|c|}
\hline Model: & & Baseli & \\
\hline Shocks: & Data & Financial. & Both \\
\hline Volatility & & & \\
\hline Standard deviations (in percent) & & & \\
\hline GDP & 1.27 & 1.06 & 1.66 \\
\hline $\begin{array}{l}\text { Standard deviations } \\
\text { relative to GDP }\end{array}$ & & & \\
\hline Consumption & 0.94 & 0.97 & 0.72 \\
\hline Hours worked & 1.03 & 1.58 & 1.03 \\
\hline Real exchange rate & 5.24 & 0.9 & 0.78 \\
\hline Labor wedge & 1.19 & 1.56 & 0.92 \\
\hline Autocorrelation & & & \\
\hline Real exchange rate & 0.72 & 0.09 & 0.42 \\
\hline Labor wedge & 0.83 & -0.14 & -0.13 \\
\hline Domestic correlations with GDP & & & \\
\hline Consumption & 0.87 & 0.999 & 0.94 \\
\hline Hours worked & 0.75 & 0.999 & 0.88 \\
\hline Labor wedge & -0.27 & -0.994 & -0.58 \\
\hline International correlations & & & \\
\hline$G D P_{U S}, G D P_{U K}$ & 0.76 & 0.61 & 0.49 \\
\hline$P C E_{U S}, P C E_{U K}$ & 0.63 & 0.6 & 0.46 \\
\hline Backus-Smith correlations & & & \\
\hline$P C E_{U S} / P C E_{U K}, Z$ & -0.22 & -0.97 & -0.02 \\
\hline$\Delta P C E_{U S} / P C E_{U K}, \Delta Z$ & -0.11 & -0.996 & -0.58 \\
\hline Non-binding constraints, in percent & & 11.32 & 10.07 \\
\hline $\begin{array}{l}\text { Variance decomposition } \\
\text { (percent of GDP explained by fin. shocks) }\end{array}$ & & 100.00 & 37.68 \\
\hline
\end{tabular}

Statistics in the first column for the volatility, autocorrelation, and domestic correlations sections are the average of the US and UK time series described in Appendix A from 1984Q1 to 2010Q4. The international correlations, autocorrelation, and Backus-Smith correlations are calculated from the US and UK time series. I also report the fraction of periods for which the borrowing constraints are not binding and the average proportion of GDP's variance attributed to financial shocks. All series have been logged (except for relative consumptions and real exchange rates in differences) and Hodrick-Prescott filtered with a smoothing parameter of 1,600 . 
presence of financial shocks. Financial shocks allow the labor wedge to be unambiguously countercyclical. This is in line with the mechanism put forward in the previous section. The same mechanism also explains the strong negative correlation between relative consumptions and real exchange rates, and the correlation in the growth of the latter two variables. Contrary to the data, labor wedges generated by the model are not persistent. This feature is related to the lack of persistent effects of financial shocks for aggregate variables. However, the estimated contribution of these shocks to GDP dynamics (37.68\%) is slightly lower than other studies. From a Bayesian estimation of a model that comprises of eight shocks, Jermann and Quadrini's (2012) variance decomposition indicates that financial shocks contribute up to 46.4 percent of GDP. Nolan and Thoenissen (2009) follow a different approach-their shocks are estimated from a New Keynesian framework that features a financial accelerator. Their median estimate for financial shocks is 46.6 percent.

The baseline model with financial shocks as the only source of shocks is also able to replicate the high level of international correlation in output. The uncovered interest rate parity (UIP) is key in understanding how these shocks propagate from a county to another. From the workers' first order conditions with respect to international bonds, the UIP is as follows:

$$
R_{H t}=E_{t} \frac{Z_{H t+1}}{Z_{H t}} R_{F t} .
$$

A positive temporary financial shock in the Home economy drives its real interest rate up as firms' demand for borrowing increases. This shift in the interest rate is transmitted to the Foreign economy from the UIP condition. As seen in the previous section, Home workers expect an appreciation of the RER (fall in $Z_{H t}$ ); however, this appreciation is too small in magnitude to offset the rise in the interest rate. The mechanism that leads to positive effects on labor demand and output in the Foreign economy diverges from the one that takes place in the Home economy. Facing a higher interest rate, Foreign firms reduce their level of inter-period debt. Their borrowing constraint is relaxed, so that the Lagrange multiplier associated with it and the labor wedge shrink. Consequently, it allows these firms to demand more labor and to increase their output, since hours worked account for the most important part of variations in output.

International correlations in GDP and consumption are lower in the third column, mainly because the estimated spill-overs from financial shocks to TFP shocks are negative. As shown in Rouillard (2015), TFP shocks lead to positive international co-movements in this environment. This is related to the domestic financial frictions that create a wedge between real 
interest rates and the marginal product of capital. On the negative side, the baseline model is not able to account for the high levels of volatility and persistence of the real exchange rates. However, this is not specific to my model as many other frameworks that feature stationary shocks also generate low volatilities and persistence. On this note, Heathcote and Perri (2014) argue that nominal exchange rates largely contribute to this specific long-standing puzzle. This constitutes a different issue that goes beyond the scope of this paper.

\subsubsection{Sensitivity analysis}

In this section, I perform a sensitivity analysis of the correlation between relative consumptions and real exchange rates. I also assess the performance of the model and its variants in replicating other key moments. Business cycle statistics are reported in Table 4 where the first and second columns correspond respectively to empirical statistics and results of the baseline model. In column 3, the statistics presented are generated from a model that differs from the baseline model on one dimension: the elasticity of substitution between intermediate goods takes a lower value, $\sigma=0.62$. This is the value that Rabanal, Rubio-Ramírez, and Tuesta (2011) use for their low elasticity scenario. As shown by Heathcote and Perri (2002), a lower value amplifies the volatility of the real exchange rate, yet it is still far below its empirical counterpart. Note that the Backus-Smith correlation is relatively lower.

In order to analyze the role of the elasticity of substitution, Figure 3 displays the correlation between relative consumptions and real exchange rates in Panel A; the correlation in the growth in the latter two variables in Panel B; and the correlation between the inverse of the marginal utility of consumption ratio and the real exchange rate in Panel C. Panels A and B display non-monotonic functions for different values of the elasticity of substitution. Nevertheless, it appears that the negative sign of the correlations is robust to higher values of trade elasticities. On that note, this is not the case for high values in the model of Corsetti, Dedola, and Leduc (2008) for their baseline persistence parameter of technology shocks to the tradable goods sector. For values of the elasticity of substitution lower than 0.6 and

higher than 1, the lower correlations displayed in Panel A can be attributed in part to the divergence between the marginal utility of consumption ratio and the real exchange rate, as can be seen in Panel C. In complete markets environment, these effects would be excluded, since the latter two variables would be perfectly correlated. However, for the baseline parameterization, the negative correlation in Panel A is due to non-separabilities of workers' 
Table 4: Sensitivity analysis statistics

\begin{tabular}{|c|c|c|c|c|c|c|}
\hline \multirow[t]{2}{*}{ Model: } & & Baseline & 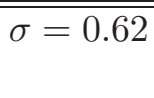 & $\overline{c \iota}=0.75$ & $\eta=2$ & $\begin{array}{c}\text { Financial } \\
\text { autarky }\end{array}$ \\
\hline & Data & & & & & \\
\hline \multicolumn{7}{|l|}{ Volatility } \\
\hline \multicolumn{7}{|l|}{ Std. dev., in percent } \\
\hline GDP & 1.27 & 1.66 & 1.65 & 1.66 & 1.48 & 1.88 \\
\hline \multicolumn{7}{|l|}{$\begin{array}{l}\text { Std. dev. } \\
\text { relative to GDP }\end{array}$} \\
\hline Consumption & 0.87 & 0.72 & 0.7 & 0.73 & 0.63 & 0.77 \\
\hline Hours worked & 1.03 & 1.03 & 1.06 & 1.02 & 0.96 & 1.17 \\
\hline Real exchange rate & 5.24 & 0.78 & 1.28 & 0.69 & 0.84 & 1.21 \\
\hline Labor wedge & 1.19 & 1.56 & 0.95 & 1.23 & 1.14 & 1.31 \\
\hline \multicolumn{7}{|l|}{ Autocorrelation } \\
\hline Real exchange rate & 0.72 & 0.42 & 0.67 & 0.38 & 0.35 & -0.19 \\
\hline Labor wedge & 0.83 & -0.14 & -0.12 & -0.14 & -0.26 & -0.43 \\
\hline \multicolumn{7}{|l|}{ Domestic corr. with GDP } \\
\hline Consumption & 0.87 & 0.94 & 0.91 & 0.94 & 0.94 & 0.93 \\
\hline Hours worked & 0.75 & 0.88 & 0.87 & 0.88 & 0.84 & 0.9 \\
\hline Labor wedge & -0.27 & -0.58 & -0.62 & -0.57 & -0.55 & -0.71 \\
\hline \multicolumn{7}{|l|}{ International corr. } \\
\hline$G D P_{U S}, G D P_{U K}$ & 0.76 & 0.49 & 0.52 & 0.5 & 0.47 & 0.17 \\
\hline$P C E_{U S}, P C E_{U K}$ & 0.63 & 0.46 & 0.61 & 0.41 & 0.38 & -0.01 \\
\hline \multicolumn{7}{|l|}{ Backus-Smith correlations } \\
\hline$P C E_{U S} / P C E_{U K}, Z$ & -0.22 & -0.02 & -0.14 & 0.05 & 0.07 & 0.94 \\
\hline$\Delta P C E_{U S} / P C E_{U K}, \Delta Z$ & -0.11 & -0.58 & -0.47 & -0.54 & -0.54 & 0.99 \\
\hline $\begin{array}{l}\text { Non-binding constraints, } \\
\text { in percent }\end{array}$ & & 10.07 & 10.48 & 10.00 & 12.02 & 20.93 \\
\hline Variance decomposition & & & & & & \\
\hline $\begin{array}{l}\text { Percent of GDP } \\
\text { explained by fin. shocks }\end{array}$ & & 37.68 & 40.08 & 36.57 & 33.67 & 52.23 \\
\hline
\end{tabular}

See the notes below Table 3 for a description of the data. Statistics of column 2 are generated from the estimation of the baseline model, and statistics of columns 3-6 are generated from variations of this model for some key parameters. Column 3 corresponds to a lower elasticity of substitution between Home and Foreign intermediate goods; column 4 to a lower parameter of equity home bias; column 5 to a lower labor Frisch elasticity; and column 6 to financial autarky. All series have been logged (except relative consumptions and real exchange rates in differences) and Hodrick-Prescott filtered with a smoothing parameter of 1,600. 

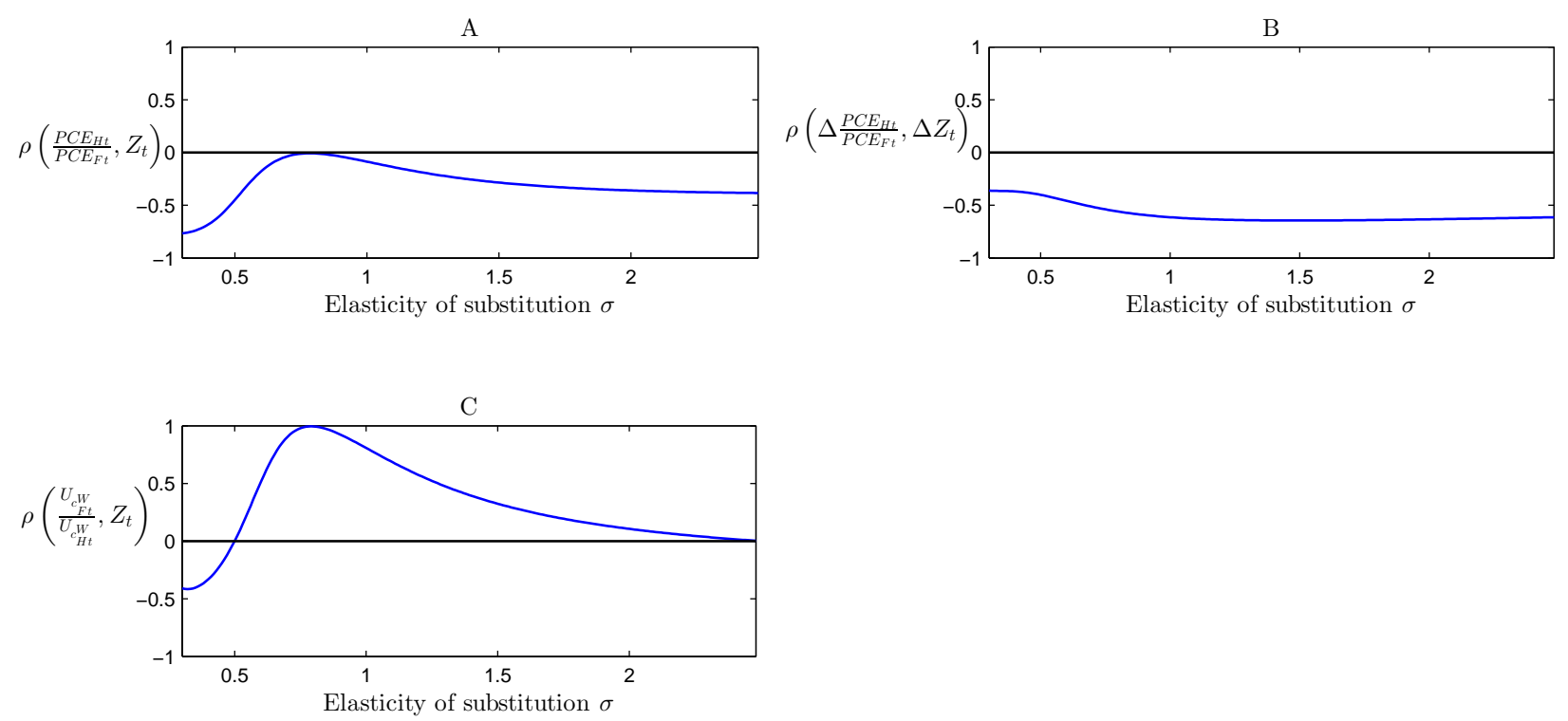

Figure 3: Sensitivity of the Backus-Smith correlation to the elasticity of substitution between intermediate goods

Panel A illustrates correlations between relative consumptions and real exchange rates; panel B illustrates correlations between the growth rates in relative consumptions and in real exchange rates; and panel C illustrates correlations between the inverse of the ratio of marginal utilities of consumption and the real exchange rate for different calibrated values of the elasticity of substitution between intermediate goods, $\sigma$.

utility function.

So far, investors have been excluded from holding shares from firms that are abroad - the equity market is autarkic up until now. In column 4, I relax this assumption, so that, in each country, domestic investors own a fraction $\iota>0.5$ of shares from domestic firms. Hence, the parameter $\iota$ corresponds to the degree of home equity bias. ${ }^{9}$ As such, in equilibrium, the investors' consumption corresponds to $c_{i t}^{P}=\iota d_{i t}+(1-\iota) Z_{i t} d_{j t}$ where $i \neq j$. For a home equity bias that corresponds to $75 \%$, the Backus-Smith correlation is positive, but it is close to zero. In Figure 4, I plot this correlation for a wide range of the parameter that controls the degree of home equity bias. In the absence of bias $(\iota=0.5)$, the effects of financial shocks are the same in both countries which is specifically the propagation channel emphasized by Perri and Quadrini (2011). This also implies that the consumption adjusted by the real exchange rate is the same for both countries. The main finding here is that a low degree of

\footnotetext{
${ }^{9} \mathrm{I}$ am grateful to an anonymous referee for her/his suggestion to pay attention to equity market segmentation.
} 

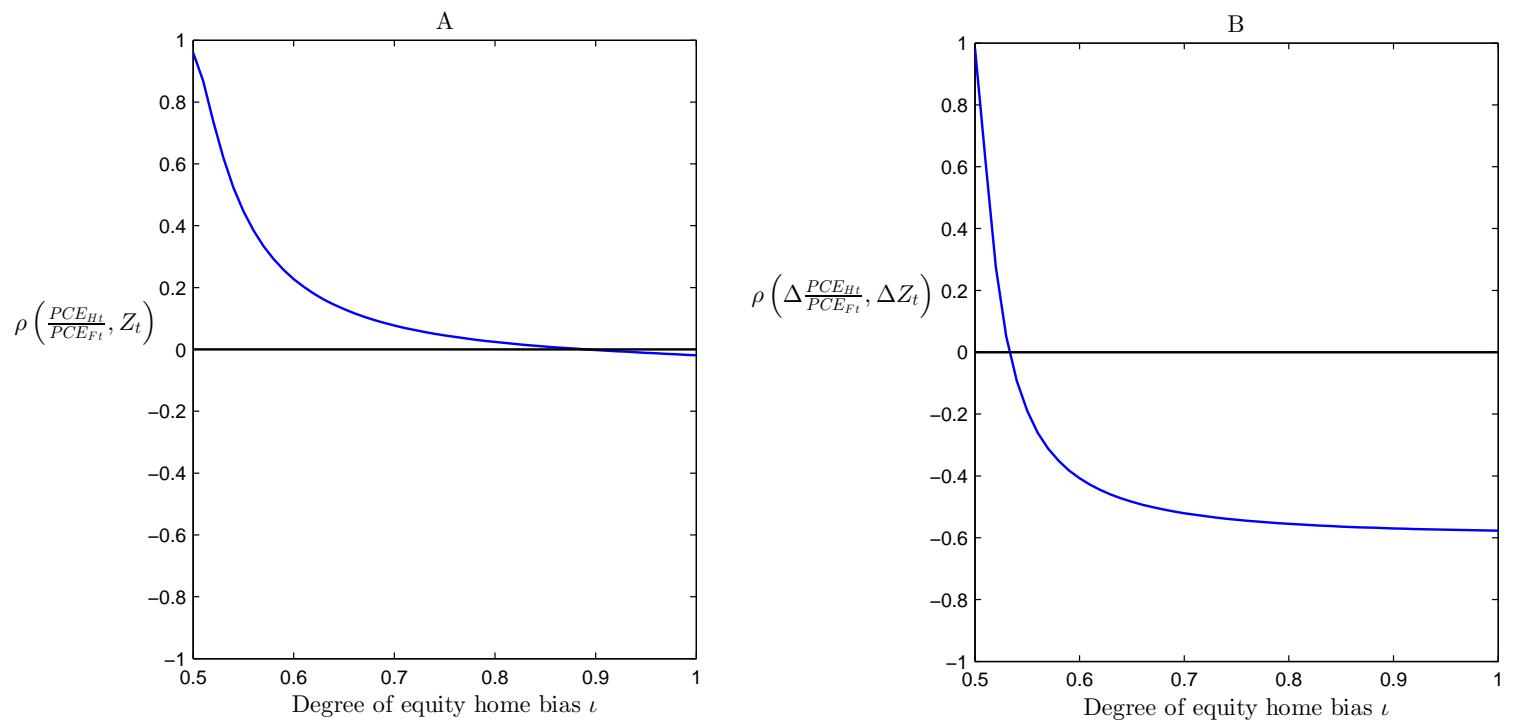

Figure 4: Sensitivity of the Backus-Smith correlation to the level of equity home bias

Panel A illustrates the Backus-Smith correlation; and panel B illustrates correlations between the growth rates in relative consumptions and real exchange rates for different values of the equity home bias, $\iota$.

home equity bias is enough to significantly pull down the Backus-Smith correlation.

In column 5, I present statistics for a lower labor Frisch elasticity that corresponds to $(\eta-1)^{-1}$ for GHH preferences. A lower elasticity implies that workers do not adjust their labor supply as much to changes in wages as seen in equation (15). This explains the lower volatility of hours worked and the lower fraction of GDP that is explained by financial shocks. Since the effects of financial shocks are less important for labor and output dynamics, the Backus-Smith correlation rises in comparison with the baseline model.

Finally, I examine the effects of changing the international asset market structure in column 6. In fact, I assume that workers can no longer trade international bonds. However, the two-good structure of the model ensures that trade still exists for intermediate goods. First, cross-country correlations are significantly reduced with financial autarky as the UIP no longer holds. Therefore, the channel described in the previous section for the propagation of financial shocks is shut down. Second, real exchange rates are more volatile since net exports are always equal to zero. Specifically, compared to the incomplete assets market structure, firms export more and import less in response to positive financial and TFP shocks. As a result, this creates greater movements in international prices in a similar fashion to Heathcote 
and Perri (2002). Third, the absence of trade balance deficits causes relative consumptions to co-move with real exchange rates. In fact, the production of the country that is hit by the financial or TFP shock increases relatively more than in the baseline model, so that the price of the intermediate good falls. Due to home bias in production of the final good, the real exchange rate in the Home economy depreciates, so that it is positively correlated with relative consumption.

\subsubsection{The Backus-Smith correlation and international efficiency}

As seen in Table 4, the correlation of relative consumptions and real exchange rates under financial autarky differs remarkably from its value under incomplete markets. Does a value closer to one implies that resources are allocated more efficiently? From a standard international real business cycle model that features separable preferences and TFP shocks, Heathcote and Perri (2014) find that the answer is yes. ${ }^{10}$ Since, under complete markets the correlation is one, lower empirical correlations are thus considered a symptom of lack of international risk sharing. As a measure of international efficiency, I compare the volatility of per-period utility functions generated by the baseline model. The standard deviation is $9 \%$ greater under financial autarky than under incomplete markets. This finding suggests that assessing international efficiency from the Backus-Smith correlation is misleading in the presence of domestic financial frictions and non-separabilities.

\section{Conclusion and extensions}

Financial shocks and non-separabilities between consumption and leisure can account for the consumption-real exchange rate anomaly. This is the main result that arises from a two-good, two-country model augmented by domestic financial frictions. Financial shocks create large fluctuations in the labor wedge that significantly affect the marginal utility of consumption. These fluctuations are so large that they break the link between relative consumptions and real exchange rates. Moreover, the correlation between these two variables is not a good indicator of the degree of international efficiency.

Exchange-rate pass-through (ERPT) is perfect in the framework presented. However,

\footnotetext{
${ }^{10}$ However, in the case of stochastic tariffs, they find that financial autarky leads to more efficient outcomes than complete markets.
} 
empirical measures of ERPT suggest that it is far from being perfect and that deviations of prices from relative purchasing power parity significantly affect international efficiency - see e.g. Burstein and Gopinath (2014). In fact, Strasser (2013) finds that the rate of ERPT is almost two times greater for financially-constrained firms than for unconstrained firms. As such, some work should be carried out to examine the relative importance of inefficiencies based on incomplete ERPT and the lack of financial integration. This research would require an extension to the baseline model, so that firms heterogeneity and different pricing decisions would have to be embedded.

\section{References}

Aguiar, M., E. Hurst, And L. Karabarbounis (2013): "Time Use During the Great Recession," The American Economic Review, 103, 1664-96.

Arellano, C., Y. Bai, And P. J. Kehoe (2012): "Financial frictions and fluctuations in volatility," Staff Report 466, Federal Reserve Bank of Minneapolis.

Backus, D. K., P. J. Kehoe, And F. E. Kydland (1994): "Dynamics of the Trade Balance and the Terms of Trade: The J-Curve?" The American Economic Review, 84, $84-103$.

Backus, D. K. And G. W. Sмith (1993): "Consumption and real exchange rates in dynamic economies with non-traded goods," Journal of International Economics, 35, 297316.

BAI, Y. AND J. ZhANG (2012): "Financial Integration and International Risk Sharing," Journal of International Economics, 86, 17-32.

Benigno, G. And C. Thoenissen (2008): "Consumption and real exchange rates with incomplete markets and non-traded goods," Journal of International Money and Finance, 27, 926-948.

Bernanke, B. S., M. Gertler, and S. Gilchrist (1999): "The financial accelerator in a quantitative business cycle framework," in Handbook of Macroeconomics, ed. by J. B. Taylor and M. Woodford, Elsevier (Amsterdam), 1341-1393.

Bodenstein, M. (2011): "Closing large open economy models," Journal of International Economics, 84, 160-177. 
Burstein, A. And G. Gopinath (2014): "International prices and exchange rates," in Handbook of International Economics, ed. by G. Gopinath, E. Helpman, and K. Rogoff, Elsevier (Amsterdam).

Campbell, J. Y. and N. G. Mankiw (1990): "Permanent Income, Current Income, and Consumption," Journal of Business 83 Economic Statistics, 8, 265-79.

Chari, V. V., P. J. Kehoe, and E. R. McGrattan (2002): "Can Sticky Price Models Generate Volatile and Persistent Real Exchange Rates?" Review of Economic Studies, 69, $533-63$.

(2007): "Business Cycle Accounting," Econometrica, 75, 781-836.

Correia, I., J. C. Neves, and S. Rebelo (1995): "Business cycles in a small open economy," European Economic Review, 39, 1089-1113.

Corsetti, G., L. Dedola, and S. Leduc (2008): "International Risk Sharing and the Transmission of Productivity Shocks," Review of Economic Studies, 75, 443-473.

Devereux, M. B. And J. Yetman (2010): "Leverage Constraints and the International Transmission of Shocks," Journal of Money, Credit and Banking, 42, 71-105.

Epstein, L. G. And S. E. Zin (1989): "Substitution, Risk Aversion, and the Temporal Behavior of Consumption and Asset Returns: A Theoretical Framework," Econometrica, $57,937-69$.

Galí, J., M. Gertler, and J. D. López-Salido (2007): "Markups, Gaps, and the Welfare Costs of Business Fluctuations," The Review of Economics and Statistics, 89, $44-59$.

Greenwood, J., Z. Hercowitz, and G. W. Huffman (1988): "Investment, Capacity Utilization, and the Real Business Cycle," The American Economic Review, 78, 402-417.

Guerrieri, L. AND M. IACOviello (2015): "OccBin: A toolkit for solving dynamic models with occasionally binding constraints easily," Journal of Monetary Economics, 70, 22-38.

Hart, O. And J. Moore (1994): "A Theory of Debt Based on the Inalienability of Human Capital," The Quarterly Journal of Economics, 109, 841-879. 
Heathcote, J. And F. Perri (2002): "Financial autarky and international business cycles," Journal of Monetary Economics, 49, 601-627.

(2014): "Assessing international efficiency," in Handbook of International Economics, ed. by G. Gopinath, E. Helpman, and K. Rogoff, Elsevier (Amsterdam).

Ho, S., P. Howard, M. Croce, and R. Colacito (2013): "BKK the EZ way. An International Production Economy with Recursive Preferences," 2013 Meeting Papers 112, Society for Economic Dynamics.

IACOViello, M. And R. Minetti (2006): "International business cycles with domestic and foreign lenders," Journal of Monetary Economics, 53, 2267-2282.

Jermann, U. And V. Quadrini (2012): "Macroeconomic Effects of Financial Shocks," The American Economic Review, 102, 238-271.

Karabarbounis, L. (2014a): "Home Production, Labor Wedges, and International Real Business Cycles," Journal of Monetary Economics, 64, 68-84.

(2014b): "The Labor Wedge: MRS vs. MPN," Review of Economic Dynamics, 17, $206-223$.

Kehoe, P. J. And F. Perri (2002): "International Business Cycles with Endogenous Incomplete Markets," Econometrica, 70, 907-928.

Mandelman, F., P. Rabanal, J. F. Rubio-Ramírez, and D. Vílan (2011): "Investment Specific Technology Shocks and International Business Cycles: An Empirical Assessment," Review of Economic Dynamics, 14, 136-155.

Mendoza, E. G. (1991): "Real Business Cycles in a Small Open Economy," The American Economic Review, 81, 797-818.

Neumeyer, P. A. And F. Perri (2005): "Business cycles in emerging economies: the role of interest rates," Journal of Monetary Economics, 52, 345-380.

Nolan, C. And C. Thoenissen (2009): "Financial shocks and the US business cycle," Journal of Monetary Economics, 56, 596-604.

Ohanian, L. E. And A. RAfFo (2012): "Aggregate Hours Worked in OECD Countries: New Measurement and Implications for Business Cycles," Journal of Monetary Economics, $59,40-56$. 
Perri, F. ANd V. Quadrini (2011): "International Recessions," Working Paper 17201, National Bureau of Economic Research.

Rabanal, P., J. F. Rubio-Ramírez, and V. Tuesta (2011): "Cointegrated TFP processes and international business cycles," Journal of Monetary Economics, 58, 156-171.

RAFFo, A. (2010): "Technology shocks: novel implications for international business cycles," International Finance Discussion Papers 992, Board of Governors.

Rouillard, J.-F. (2015): "National Financial Frictions and International Business Cycle Synchronization," Working paper GREDI15-12, Université de Sherbrooke.

Shimer, R. (2009): "Convergence in Macroeconomics: The Labor Wedge," American Economic Journal: Macroeconomics, 1, 280-97.

Strasser, G. (2013): "Exchange rate pass-through and credit constraints," Journal of Monetary Economics, 60, 25-38.

\section{A Data sources and construction of variables}

\section{A.1 United States}

Variable name: CPI

Source: BLS

Definition: U.S. City Average (Quarter Average, Seasonally Adjusted)

Variable name: Price Index for Nonfarm Business Value Added

Source: BEA, NIPA, Table 1.3.4

Definition: Index 2005=100 (Seasonally Adjusted)

Variable name: Net New Borrowing

Source: Federal Reserve Board, Table F.101

Definition: Net increase in credit markets instruments of non-financial business (Quarter Average, 
Seasonally Adjusted)

Deflator used: Price Index for Business Value Added

Variable name: Business Value Added $\left(Y_{U S}\right)$

Source: NIPA 1.3.5

Deflator: Index for business value added (NIPA 1.3.4) (seasonally adjusted)

Variable names: Real Consumption $\left(C_{U S}\right)$

Real Net Exports of Goods and Services $\left(N X_{U S}\right)$

Source: BEA, NIPA, Table 1.1.6

Definition: Billions of chained (2005) dollars (Seasonally adjusted)

Variable names: Total Employment

Hours worked per worker

Source: Ohanian and Raffo (2012)

Definition: The product of these two variables is equal to $N_{U S}$

Variable names: Consumption of Fixed Capital in Non-Financial Corporate Business Consumption of Fixed Capital in Non-Financial Non-Corporate Business

Source: Federal Reserve Statistical Release, Flow of Funds, Table F.8

Definition: Millions of US Dollars (Quarterly)

Deflator used: Business Value Added

Variable name: Terms of trade $\left(T O T_{U S}\right)$

Source: International Financial Statistics (IFS)

Definition: Ratio of Implicit Price Deflator Indices for Imports and Exports of Goods and Services

\section{A.2 United Kingdom}

Variable name: CPI

Source: OECD, Prices

Definition: All items (seasonally adjusted with X12-ARIMA) 
Variable name: Domestic Loans $\left(e_{U K}\right)$

Source: Bank of England, LPQVVOJ

Definition: Quarterly amounts outstanding of monetary financial institutions' sterling net lending to private non-financial corporations (Seasonally Adjusted)

Deflator used: CPI

Variable name: Consumption $\left(C_{U K}\right)$

Source: OECD, Quarterly National Accounts

Definition: Chained-volume estimates (2005 in pounds) (seasonally adjusted)

Variable names: Gross domestic product index (seasonally adjusted) ( $\left.Y_{U K}\right)$

Gross Fixed Capital Formation: Total GFCF (seasonally adjusted)

Total capital consumption (seasonally adjusted)

Source: ONS (YBEZ, NPQT, CIHA)

Definition: Millions of pounds

Variable names: Total Employment

Hours worked per worker

Source: Ohanian and Raffo (2012)

Definition: The product of those two variables is equal to $N_{U K}$

Variable name: Terms of trade $\left(T O T_{U K}\right)$

Source: International Financial Statistics

Definition: Ratio of Implicit Price Deflator Indices for Imports and Exports of Goods and Services

\section{A.3 Construction of variables}

$K_{U S}$ is constructed recursively in the same way as described in the appendix of Jermann and Quadrini (2012). I pick the initial value of $K_{U S}$ for the first quarter of 1952 such that the capitaloutput ratio does not exhibit any trend over the period 1952-2010. Depreciation corresponds to the sum of Non-Financial Corporate and Non-Corporate Business Consumption of Fixed Capital and Investment to Capital Expenditures in Non-Financial Business.

$$
K_{U S t+1}=K_{U S t}-\text { Depreciation }+ \text { Investment }
$$


For the United Kingdom, the recursion is similar to the one described for the United States and in this case the period is slightly shorter: 1955-2010. Investment corresponds to Total Gross Fixed Capital Formation and Depreciation to Total Capital Consumption.

Inter-period debt $e_{U S t}$ is also constructed recursively in the same way as described in the appendix of Jermann and Quadrini (2012). The initial value for the (nominal) stock of debt is set to 94.12, which is the value reported in the balance sheet data from the Flow of Funds in the first quarter of 1952 for the nonfarm non-financial business (Table B.102, line 22).

$$
e_{U S t+1}=e_{U S t}+\text { NetNewBorrowing }
$$

The terms of trade series (TOT) corresponds to the ratio of the implicit price deflator for imports to the implicit price deflator for exports (NIPA 1.1.9). The real exchange exchange $(Z)$ corresponds to the ratio of the UK and the US CPIs multiplied by the quarterly average nominal exchange rate that is retrieved from the FRED database of the St.Louis Fed.

\section{B Recursive formulation and first order conditions}

\section{B.1 Firms' problem}

The firms' recursive problem is the following:

$$
\begin{aligned}
V\left(\mathbf{s}_{\mathbf{i}} ; k_{i}, x_{i}, e_{i}^{P}\right)= & \max _{d_{i}, n_{i}, k_{i}^{\prime}, e_{i}^{P^{\prime}}}\left\{d_{i}+E m_{i}^{\prime} V\left(\mathbf{s}_{\mathbf{i}}^{\prime} ; k_{i}^{\prime}, e_{i}^{P^{\prime}}\right)\right\} \\
& \text { subject to: } \\
& p_{i i} y_{i}+e_{i}^{P^{\prime}}-w_{i} n_{i}=d_{i}+k_{i}^{\prime}-(1-\delta) k_{i}+R_{i} e_{i}^{P}, \\
& \lambda_{i} k_{i}^{\prime} \geq e_{i}^{P^{\prime}}+p_{i i} y_{i} .
\end{aligned}
$$

The value of firms, $V\left(\mathbf{s}_{\mathbf{i}} ; k_{i}, x_{i}, e_{i}^{P}\right)$ corresponds to the sum of the discounted stream of dividends where $m_{i}$ corresponds to the stochastic discount factor. Output $y_{i}$ is priced in terms of the expenditure good. Firms optimize with respect to $n_{i}, e_{i}^{P^{\prime}}$, and $k_{i}^{\prime}$. The FOCs are as follows: 


$$
\begin{aligned}
Y_{n i} & =\frac{w_{i}}{1-\vartheta_{i}} \\
1 & =E m_{i}^{\prime} R_{i}^{\prime}+\vartheta_{i} \\
1 & =\lambda_{i} \vartheta_{i}+E m_{i}^{\prime}\left(p_{i i} y_{k^{\prime} i}\left(1-\vartheta_{i}^{\prime}\right)+1-\delta\right)
\end{aligned}
$$

where $\vartheta_{i}$ corresponds to the Lagrange multiplier associated to the borrowing constraint. Equation (30) corresponds to the FOC with respect to labor. Equation (31) refers to an Euler equation augmented with a borrowing constraint. Equation (32) corresponds to the FOC with respect to capital.

\section{B.2 Investors' problem}

Investors optimize their problem by picking consumption and the quantity of shares. The combination of their FOCs correspond to the following Euler equation:

$$
\frac{p_{i t}^{s}}{c_{i t}^{P}}=\gamma \frac{E_{t}\left(d_{i t+1}+p_{i t+1}^{s}\right)}{c_{i t+1}^{P}} .
$$

\section{B.3 Workers' problem}

The workers' FOCs are as follows:

$$
\begin{aligned}
\frac{U_{c_{H t}^{W}}}{E_{t}\left(U_{c_{H t+1}^{W}}\right)} & =\frac{\beta_{H t}}{\beta_{F t}} \frac{U_{c_{F t}^{W}}}{E_{t}\left(U_{c_{F t+1}^{W}}\right)} \frac{E_{t}\left(Z_{t+1}\right)}{Z_{t}}, \\
E_{t}\left(\frac{Z_{t}}{Z_{t+1}} R_{H t}\right) & =R_{F t}=R_{t}, \\
\zeta n_{i t}^{\eta-1} & =w_{i t},
\end{aligned}
$$

The FOC with respect to consumption combined to FOcs with respect to the international bond for both Home and Foreign workers gives equation (34). The combination of FOCs with respect to the international bond and inter-period debt corresponds to equation (35), that is also called the uncovered interest rate parity (UIP). Equation (36) represents the relationship between wages and labor supply. 